\title{
ANOROGENIC GRANITOIDS OF THE EARLY PRECAMBRIAN MAGMATISM OF THE UKRAINIAN SHIELD
}

\author{
K. I. SVESHNIKOV, Yu. T. SUKHORUKOV, \\ I. K. PASHKEVICH and S.S. KRASOVSKY
}

SVESHNIKOV, K. I.; SUKHORUKOV, Yu. T.; PASHKEVICH, I. K. and KRASOVSKY, S.S. 1993. Anorogenic granitoids of the Early Precambrian magmatism of the Ukrainian shield. Bull. Geol. Soc. Finland 65, Part II, 119130.

The Early Precambrian magmatism of the Ukrainian shield evolved through regular changes in tectonic setting, composition and depth of formation of rocks of three magmatic associations:(1) granitic, (2) dioritegranitic and (3) anorthosite-granitic. They correspond to the S, I, A - gtanite types respectively.

The Early Proterozoic anorogenic granitoids of the Ukrainian shield are represented by the Korosten and Korsun-Novomirgorod rapakivi massifs, East-Peri-Asov complex of subalkaline granites, syenites and nepheline syenites, Perzhansk complex of subalkaline granites and rare-metal metasomatites.

The anorogenic granitoids differ from magmatic rocks of the preceeding granitic and diorite-granitic associations by tectonic setting and composition. They are considered to belong to final stage of magmatic evolution and development of consolidated mature Early Proterozoic crust.

The anorogenic granitoids of the Ukrainian shield are controlled by a major north-west linear magmatogenic structure, extending trough the whole Ukrainian shield to Poland.

Key words: granites, rapakivi, syenites, tectonic controls, igneous activity, Ukrainian shield, Proterozoic, Ukraine.

Sveshnikov, K. I. : Lvov State University. 290005 Lvov, Ukraine

Sukhorukov, Yu. T. : Institute of the Lithosphere, Russian Akademy of Sciences, 109180, Moscow, Russia.

Pashkevich, I. K. and Krasovsky S.S. : Institute of Geophysics, Ukrainian Akademy of Sciences, 252680, Kiev, Ukraine. 


\section{INTRODUCTION}

The aim of this paper is to reviw the geology of anorogenic granitoids of the Ukrainian shield, using geological, geophysical and geochemical data. The authors intended: (1) to consider the rapakivi magmatism as a part of the anorogenic magmatism of the Ukrainian shield, (2) to relate the anorogenic magmatism to the whole Early Precambrian magmatism of the Ukrainian shield, and (3) to link the evolution of the Early Precambrian magmatism with the crust structure and its evolution.

In what way the granitoids of the preceeding stages of the magmatic evolution are related to the anorogenic granitoids is a key question. Different magmatic bodies, which are not associated genetically with each other often are dated to have the same age and attrbuted to the same tectonomagmatic cycle. Such a controversy can be better resolved, if one studies these magmatic bodies in terms of general tectonic setting of the area and their relations between themselves and with country rocks. This approach led to the distinguishing of magmatic associations-communities of magmatic bodies, which are close to each other in origin and tectonic setting. All the Early Precambrian magmatic rocks of the Ukrainian shield are subdivided into three magmatic associations: (1) granitic, (2) dioritegranitic, (3) anorthosite-granitic. The granitoids of these assocoations correspond respectively to the S, I, and A - granite types (Chappel and White 1974, Pitcher 1987). The anorogenic granitoids belong to the anorthosite-granitic association.

\section{GEOLOGICAL SETTING OF THE ANOROGENIC GRANITOIDS}

The anorogenic granitoids of the Ukrainian shield include two classic rapakivi massifs; the Korosten and the Korsun-Novomirgorod as well as the EastPeri- Azov complex of subalkaline granites, syenites and nepheline syenites, and the Perzhansk complex of subalkaline granites and rare-metal metasomatites. The geology of these two rapakivi masifs as the most important representatives of the anorogenic granitoids is reviewed below.

The subisometric Korosten massif occupies an area of $12,000 \mathrm{~km}^{2}$ in the nortwestern part of the shield (Figs 1 and 2). It is controlled by ring and linear predominatly diagonal faults. One of the major structures, controlling emplacement of the massif, is a long northeastern mantle-rooted lineament, whose existence has been established by geophysical data (Sollogub 1986; Fig. 1). The northern edge of the massif is limited by latitudinal the Ovruch trough, filled with continental unmetamorphosed sedimentary and volcanic rocks dated at $1650 \mathrm{Ma}$ (U-Pb zircon age, Lazko 1989).

The country rocks are gneisses, schists, migmatites of the metaterrigenous Teterevsk group, intruded by autochthonous granitoids of the Zhitomirsk complex. The Korosten massif and surrounding rocks occopy an subisometric area, which is believed to be a large ring structure, determined by satelite and air photos (Gintov 1974). This area is interpreted as a Lower Proterozoic depression, hosting the Korosten massif in its central part.

According to Sollogub (1986), the massif is a horizontally lying plate-like body, consisting of several intercalated granitic and gabbro-noriteanorthosite plates with a total thickness of about 6 $\mathrm{km}$. The crust of this area is thinner (about $40 \mathrm{~km}$ ) than the neighbouring blocks of the shield. Crustmantle boundaries were established at the base of the crust. The contacts of the massif with country rocks are cleary intrusive. The massif contains basic rocks (anorthosites, gabbro-anorthosites, gabbro-norites), which constitute several subisometric or irregular bodies. The gabbro-norites are confined mainly to the edges of the anorthosite bodies and are considered to be a marginal complex of the anorthosites (Esipchuk 1990). The inner structure of the massif is complicated by large xenoliths of Archean gneisses, schists, migmatites and gneisses of the Teterevsk group. The granitoids occopy the larger part of the massif. Different investigators distinguish up to eight compositional varieties of the granitoids (Lichak 1983, Esipchuk 1988). Compositional comparison of two Ukrainian and three Baltic rapakivi massifs shows that the 


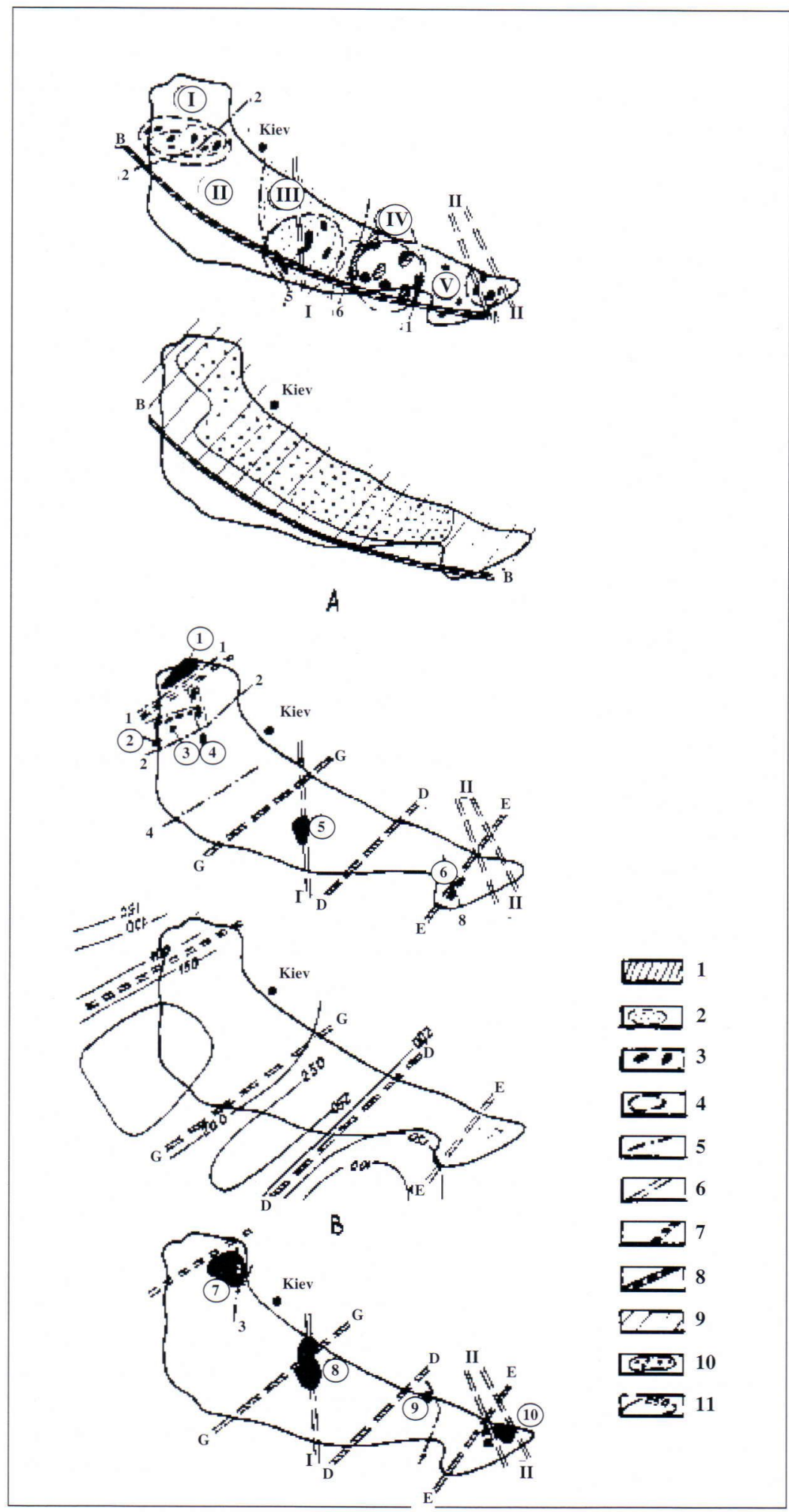

Fig. 1 Sketch map showing the mode of distribution of magmatic association in their relations to the crust structure. Magmatic associations: $A=$ granitic, $B=$ dioritegranitic, $C=$ anorthosite-granitic. $1=$ structures composed of greenstone complex, 2 = structures composed of metaterrigenous complex, $3=$ plutonic bodies, $4=$ contours of magmatic areas, $5=$ deep-seated faults, $6=$ transregional tectonic faults, $7=$ mantle-rooted lineaments, $8=$

lineament " $B$ ", $9=$ area with crust, containing the reflecting horizon $K 2,10$ = regional minimum of magnetic anomaly, $11=$ depth of the

asthenosphere boundary. Plutonic massifs (arabic figures in circles): $1=$ massifs of the VolynoPolessk volcano-plutonic belt, 2 = Shepetovsk, $3=$ Smoldyrevsk, $4=$ Bukinsk, $5=$

Novoukrainsk, $6=$ Saltychansk, $7=$ Korosten, $8=$ KorsunNovomirgorod, $9=$ Malotersyansk, $10=$ East-Peri-Azov group of massifs. Faults (arabic figures without circles): $1=$ Sushchano Perzhansk, 2 = Teterevsk, $3=$ Brusilovsk, $4=$ Nemirovsk, $5=$ Pervomaisk, $6=$ KrivorozhskoKremenchugsk, 7 = Orechovo-Pavlogradsk, $8=$ Sorokinsk .

Transregional faults (roman figures): $1=$ Kherson-Smolensk, $I I=$ Donetsk-Bryansk. 


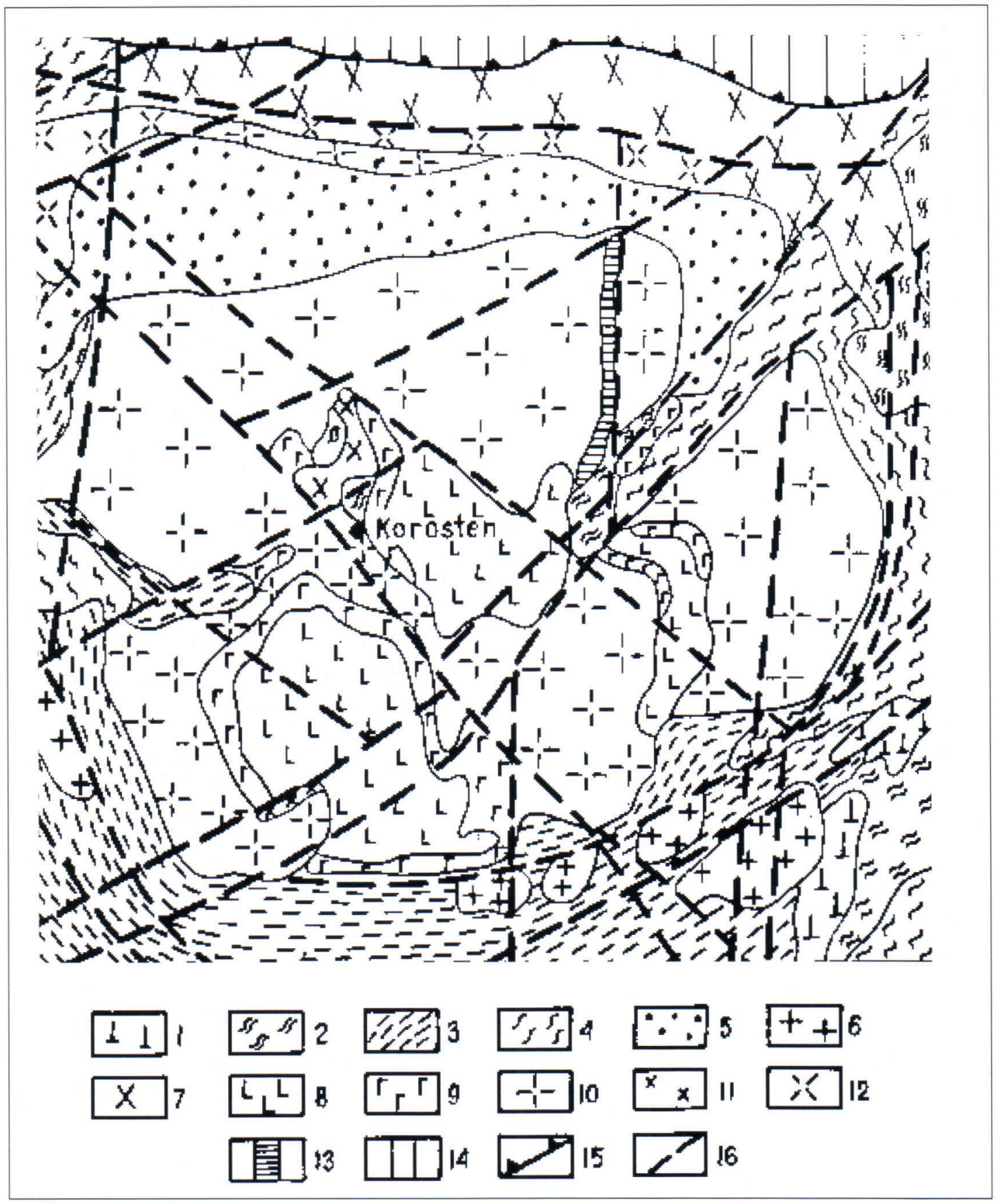

Fig. 2. Sketch of the Korosten rapakivi massif geological setting, Archean complexes: $1=$ amphibolites, gneisses, 2 = migmatites, plagiogranites. Proterozoic complex: $3=$ schists, gneisses of the Teterevsk group, $4=$ migmatites, 5 = quartzites, sandstones, volcanics of the Ovruchsk group, $6=$ granitoids of the KirovogradZhitomirsk complex, $7=$ granitoids of the Volyno-Polessk belt. The Korosten massif: $8=$ anorthhosites, gabbroanorthosites, 9 = gabbro-norites, 10 = biotite-hornblende, biotite granites, 11 = albite-fluorite-topaz-bearing granites, 12 = subalkaline granites and rare-metal metasomatites of the Perzhansk complex, $13=$ gabbrodiabase, 14 = Dnieper -Donetsk Trough, $15=$ boundary of the Ukrainian shield, $16=$ faults. 
rapakivi granitoids fall into the four main compositional varieties: (1) quartz monzonites, (2) biotite-hornblende ovoid, porphyritic and evengranied granites, (3) even-grained biotite granites, (4) albite-fluorite-topaz-bearing granites (Sukhorukov 1989). Each of these varietes can be subdivided into many subvarieties differing from each other by texture and fabrics. The typical biotitehornblende ovoid granites occopy a rather small area in the northeastern part of the massif. The transition zones between different varieties are gradual, and it is difficult to outline the boundaries between them. The Ukrainian rapakivi are characterized by the small size of potassium feldspar ovoids and lack of clear boundaries between granitoid varieties; they are less differentiated than the Baltic rapakivi. These features suggest a deeper level of erosion in the Ukrainian rapakivi in comparison with the Baltic ones (Sukhorukov 1989). A small elongated body of albite-fluorite-topazbearing granites is known in the southwestern part of the massif. Their composition is close to that of the apical albite granites of the Salmi massif in Karelia but rare-metal metasomatites were not established in the Korosten massif.

The Korsun-Novomirgorod rapakivi massif is confined to the central part of the shield and occupies an area of about $5,000 \mathrm{~km}^{2}$ (Fig. 3) . There are many similarities in tectonic setting and composition of the Korsun-Novomirgorod and the Korosten rapakivi massifs. The Korsun-Novomirgorod massif is confined to an Early Proterozoic depression filled with metaterrigenous rocks of the Ingulo-Inguletsk group, correlated with the Teterevsk group; it has intrusive relations with country rocks and bimodal composition (Sveshnikov 1981). Nevertheless, some specific features of the Korsun-Novomirgorod massif should be mentioned: (1) The massif is an oval elongated body, confined to the intersection of a major transregional submeridional fault zone (Sveshnikov and Sukhoruko 1990) with a mantlerooted lineament (lineament G-Gin Fig. 1., Sollogub 1986). (2) The main system of linear structures is orthogonal. (3) Ring structures are complicated; in addition to the major elongated oval ring structure of the massif, there are two minor ring structures (concenters), constituting the northern and southern parts of the massif. (4) There are very few xenoliths of country rocks inside the massif. This fact can be explained by the deeper erosional level of the massif in comparison with the Korosten massif. (5) Quartz monzonite is rather common variety in the Korsun-Novomirgorod massif (it is practically absent in the Korosten massif).

The origin of quartz monzinite is a subject to controversy. At least three types of quartz monzonites can be distinguished:

(1) Thin $(3-5 \mathrm{~m})$ transition zones of quartz monzonites at the contacts of gabbro-norites and granites; (2) rather thick (more than several hundred metres) lense-like bodies, located between granites and gabbro-norites. These bodies have clear contacts both with granites and gabbro-norites; (3) dyke-like bodies of quartz monzonites traced in granites far away from their contacts with gabbronorites. The thin contact monzonites are supposed to originate by interaction of later granitic melt with already solidified gabbro-norite, whereas the lenslike and dyke-like monzonites formed from monzonitic hybrid melts, which originated at depth.

\section{MAGMATIC \\ ASSOCIATIONS AND EVOLUTION OF GRANITOID MAGMATISM}

The granitic association includes autochthonous and partly allochthonous plagiogranite, tonalite, biotite and biotite-muscovite granite and leucogranite of Archean and Early Proterozoic ages. They are associated with granulite and amphibolitegneiss complexes, extensively metamorphosed, migmatized, granitized and deformed.

In spite of very prolonged time span between the ages of the Late Archean (3000-2900 Ma) and Early Proterozoic (2420 Ma) members of this association (U-Pb zircon determinations; Shcherbak 1989) both are very close to each other in tectonic setting and composition. They are characterised by equal aluminosity, determined by values of a coefficient of relative aluminosity (Fig. 4), have a low abundances of heavy REE and a weakly 


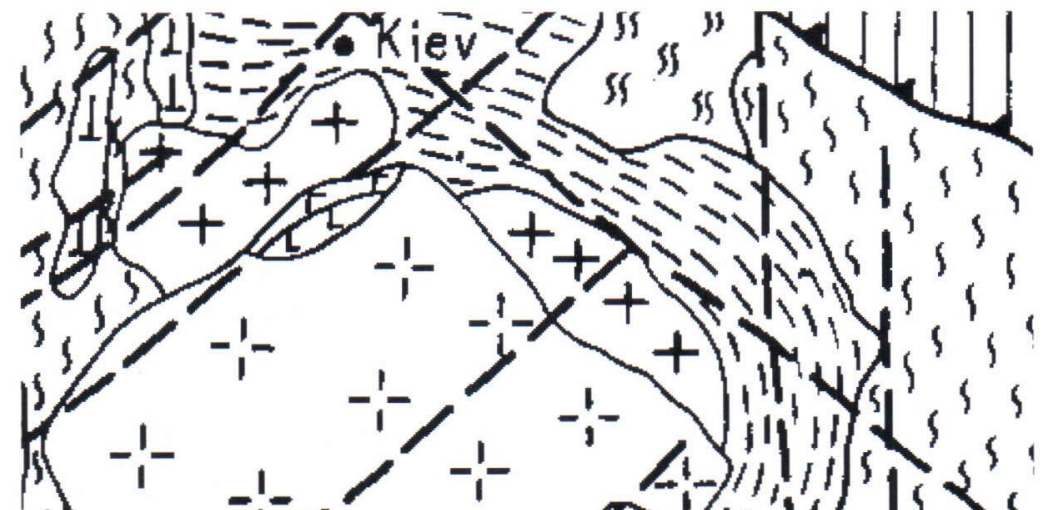
Sh

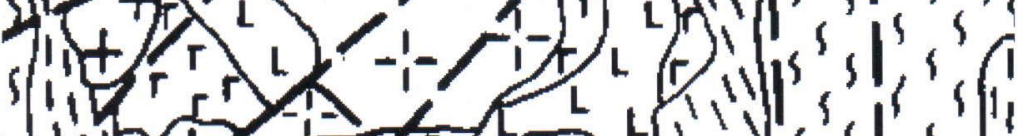

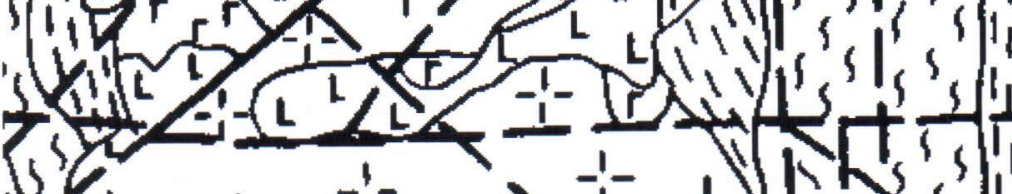

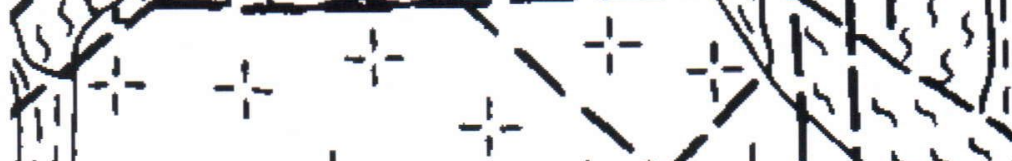
(n)

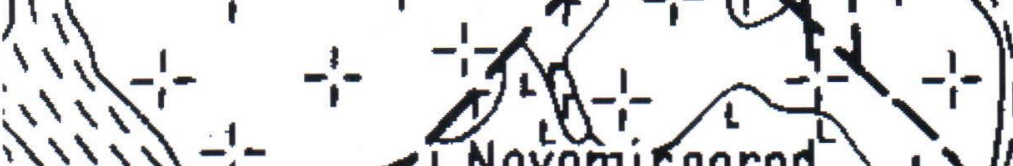
....... Thovomi gorod

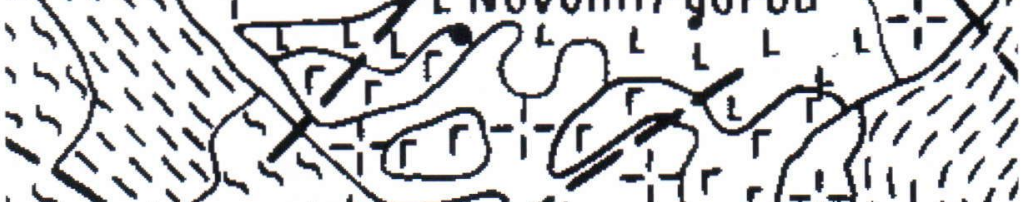

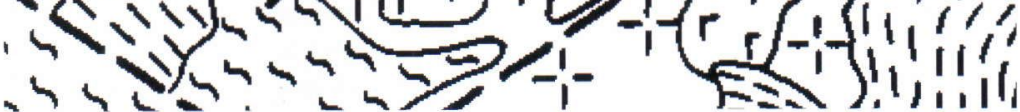

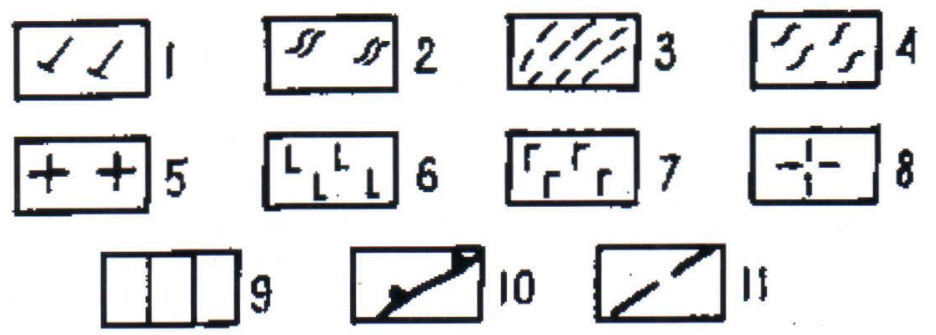

Fig. 3. Sketch map of the KorsunNovomirgorod rapakivi massif geological setting. Archean

complexes: $1=$ amphibolites, 2 = migmatites,

tonalites.

Proterozoic

complexes: 3 = schists, gneisses of the Ingulo-

Inguletsk group, 4 $=$ migmatites, $5=$ granitoids of the KirovogradZhitomirsk complex. KorsunNovomirgorod rapakivi massif: 6 = anorthosites, gabbro-

anorthosites, $7=$ gabbro-norites, 8 = quartz monzonites, biotite hornblende, biotite granites, $9=$ Dnieper-Donetsk Trough, $10=$ boundary of the Ukrainian shield, 11 = faults. 
expressed Eu minimum (Fig. 5).

The granitoids are confined to rather large (150 x $100 \mathrm{~km}$ ) subisometric or oval areas all over the shield, containing "clusters" of magmatic bodies (Fig. 1). The distribution of these areas is limited by a northwestern lineament "B" (see Fig. 1), dividing the shield into two areas: (1) the northern area, composed of a two-layer crust (dioritic and granitic) and (2) the southern area, having a one-layer crust (granitic). North of lineament "B" a reflecting seismic $\mathrm{K} 2$ horizon is interpreted to be the deepest level of granitization and magma generation of granitoids in the granitic association.
The diorite-granitic association includes gabbrodiorite, quartz monzonite, granodiorite, and biotite granite. Numerous various size intrusive bodies of these rocks and comagmatic volcanics (basalt, andesite, trachyrhyolite) constitute a northeasterly trending Volyno-Polessk volcano-plutonic belt (Aksamentova and Naidenkov 1991, see Fig. 1. ). The belt is a boundary structure, separating the Ukrainian shield and Belorussian crystalline massif. The intrusive and volcanic rocks of the belt have U$\mathrm{Pb}$ zircon ages of 2100-1950 Ma (Verkhoglyad 1988). The preliminary data suggest that southeast of the belt graitoids of the association (the

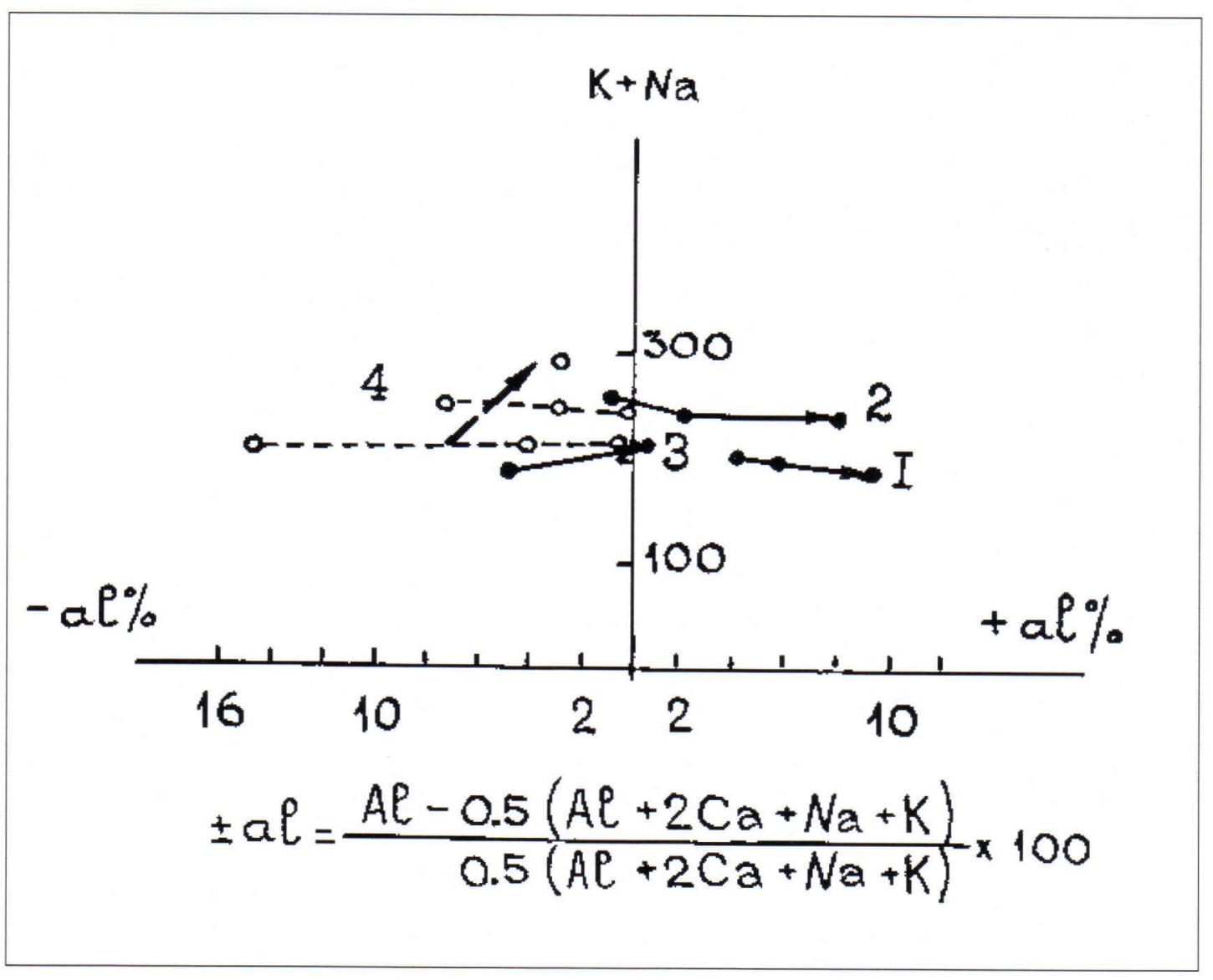

Fig.4. Relative aluminosity-alkalinity in granitoids of the Ukrainian shield. Granitoids of the granitic association: 1 = Late Archean granitoids of the central part of the Ukrainian shield, $2=$ Early Proterozoic granitoids of the northwestern part of the shield, $3=$ granitoids of the diorite-granitic association, $4=$ granitoids of the anorthosite-granitic association of the Korosten massif. The arrows show evolution of compositions within each association. 
Fig.5. Normalized rare earth element abundances in granitoids of the Ukrainian shield. 1 = gneisses after metaterrigenous rocks. Granitic association, Late Archean granitoid massifs: 2 = Tokovsk, 3 = Mokromoskovsk. Early Poterozoic granitoid massifs: 4 = Kirovogradsk, $5=$ Zhitomirsk. Dioritegranitic association, granitoid massifs: 6 $=$ Osnitsk, 7 = Mukharevsk, $8=$ Novoukrainsk, $9=$ Saltychansk.

Anorthosite-granitic association,

granitoid massifs: $10=$ Korosten, $11=$ Korsun-

Novomirgorod, $12=$ East-Peri-Azov.

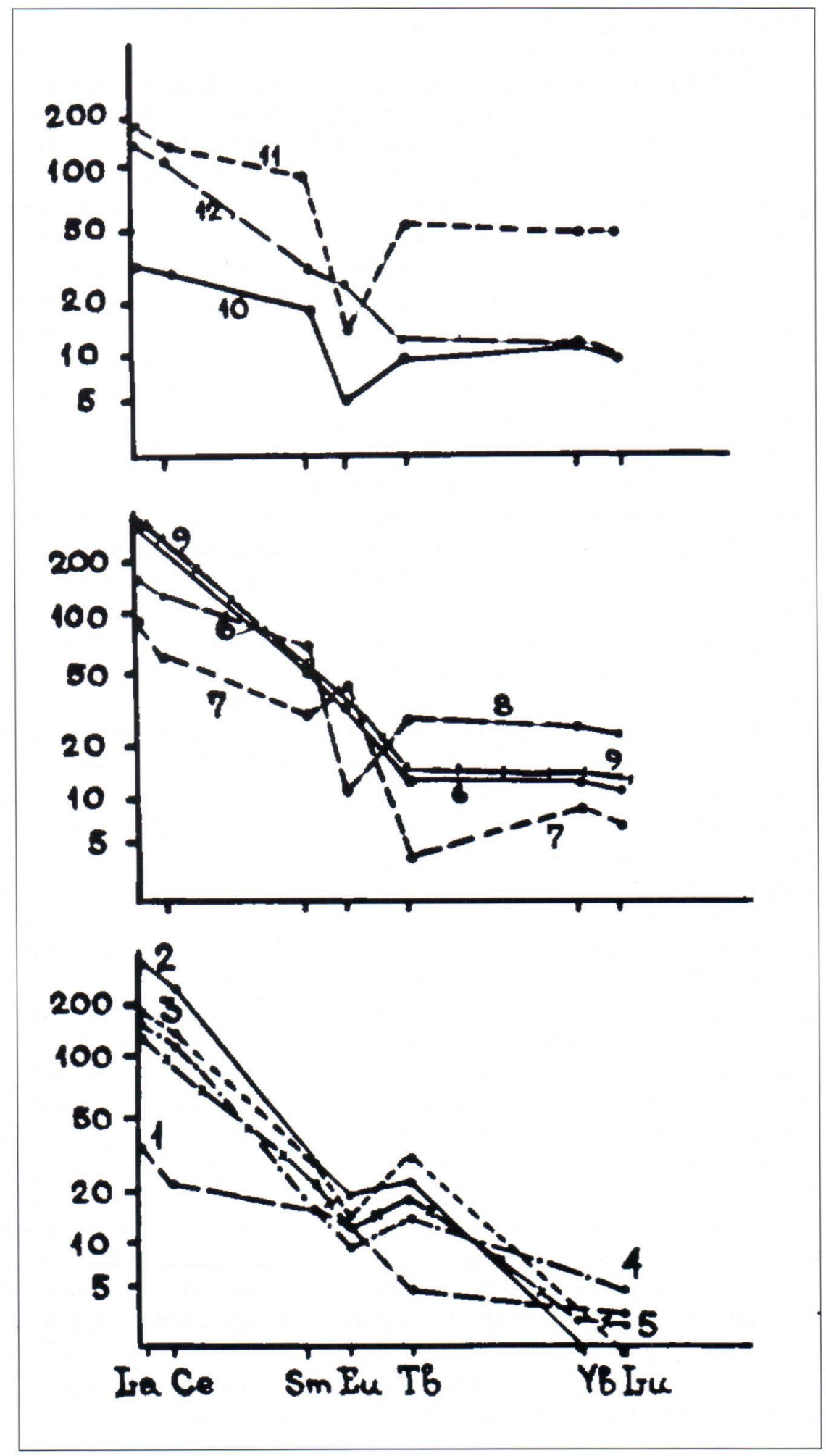


Shepetovsk, Smoldyrevsk, Bukinsk and other massifs) become younger. The biotite granites of the association differ from granites of the granitic association by lower aluminosity (Fig. 4) and higher abundances of REE (Fig. 5). Several mantle-rooted lineaments G, D, E, (Sollogub 1986) are supposed to control the formation of granitoid massifs of the association (Fig. 1). The lineament, controlling the Volyno-Polessk belt, was determined as dipping steeply to the southeast, i.e. toward the Ukrainian shield (Sollogub 1986). The belt is characterized by the maximal thickness of the basalt layer of the crust and the minimum depth of the boundary between the crust and asthenosphere. This boundary has also the minimum depth below the G, D, E lineaments.

The formation of the Volyno-Polessk belt is related to restructuring of the whole northwestern part of the shield. Unlike the other areas of the shield the northeastern structures here are dominant. This restructuring corresponds to change of strike of the isohypses here from the northwestern to the northeastern and sublatitudinal (Chekunov and Pashkevich 1989, see Fig. 1).

The anorogenic anorthosite-granitic association includes granitoids, which are close to each other in tectonic setting, composition and $\mathrm{U}-\mathrm{Pb}$ zircon ages (the Korosten massif 1820-1895 Ma, Korsun Novomirgorod massif $1740 \mathrm{Ma}$, East-Peri-Azov complex $1650 \mathrm{Ma}$, Perzhansk complex 1720-1760 Ma; Shcherbak1984, 1989 ).

The massifs of the East-Peri-Azov complex are comparable with the rapakivi massifs in size and morphology. They are located at the intersection of the mantle-rooted lineament "E" and transregional fault II (Fig. 1). Elongated bodies of granites and zones of rare-metal metasomatites of the Perzhansk complex occur in the vicinity of the Korosten massif and are controlled by the northeastern and latitudinal faults.

The granitoids of the anorthosite-granite association are low in aluminosity, high in alkalinity and have more pronounced $\mathrm{Eu}$ minimum in comparison with granitoids of the diorite-granite association (Figs 4 and 5). All anorogenic massifs are distributed in a chain-like pattern along a line extending from the Azov to the Baltic Sea (Fig. 6).
The northwestern continuation of this chain of the Ukrainian anorogenic granitoids is represented by the Zhitkovichsk and Mostovsk complex in Belorussia (Aksamentova and Naidenkov 1991) and the Mazursk rapakivi complex in Poland. The Dnieper-Donetsk Trough coincides with the above line and all the Ukrainian anorogenic granitoids are located near the southwestern edge of the DnieperDonetsk Trough. The chain of anorogenic granitoids, as well as the Dnieper-Donetsk Trough are correlated with the axial part of a global MAGSAT Za magnetic anomaly (Haines 1985, Fig. 6).

\section{DISCUSSION}

The review presented above on age, geology and composition of the magmatic associations enables one to outline some features of the geodynamic environment of the anorogenic granitoids and their evolution as the background of the evolution of Early Precambrian magmatism in the Ukrainian shield.

(1) The temporal relations between granitoids within the each association suggest some age shift for separate massifs that can be correlated with their spatial distribution. Such an age shift for granitoids of the granitic association (the granitoids become younger away to the west and east from the central part of the shield) differs from that of granitoids of the diorite-granitic association (younger ages from the west to the east). It would be tempting to explain the east trending granitoid age shift (from older to younger), as well as the petrochemical zonation (from less to more alkaline) for the diorite granitic and anorthosite-granitic associations by an evolutional change from the I to A-granite types, related to collisional processes within the VolynoPolessk belt. Windley (1991) proposes such an interpretation for the development of the Ketilidian orogen and formation of the post-orogenic rapakivi granitoids in South Greenland. Such an interpretation, being quite convincing for a separate, rather limited area could be hardly applied to the rapakivi massifs of the whole East European Platform. 


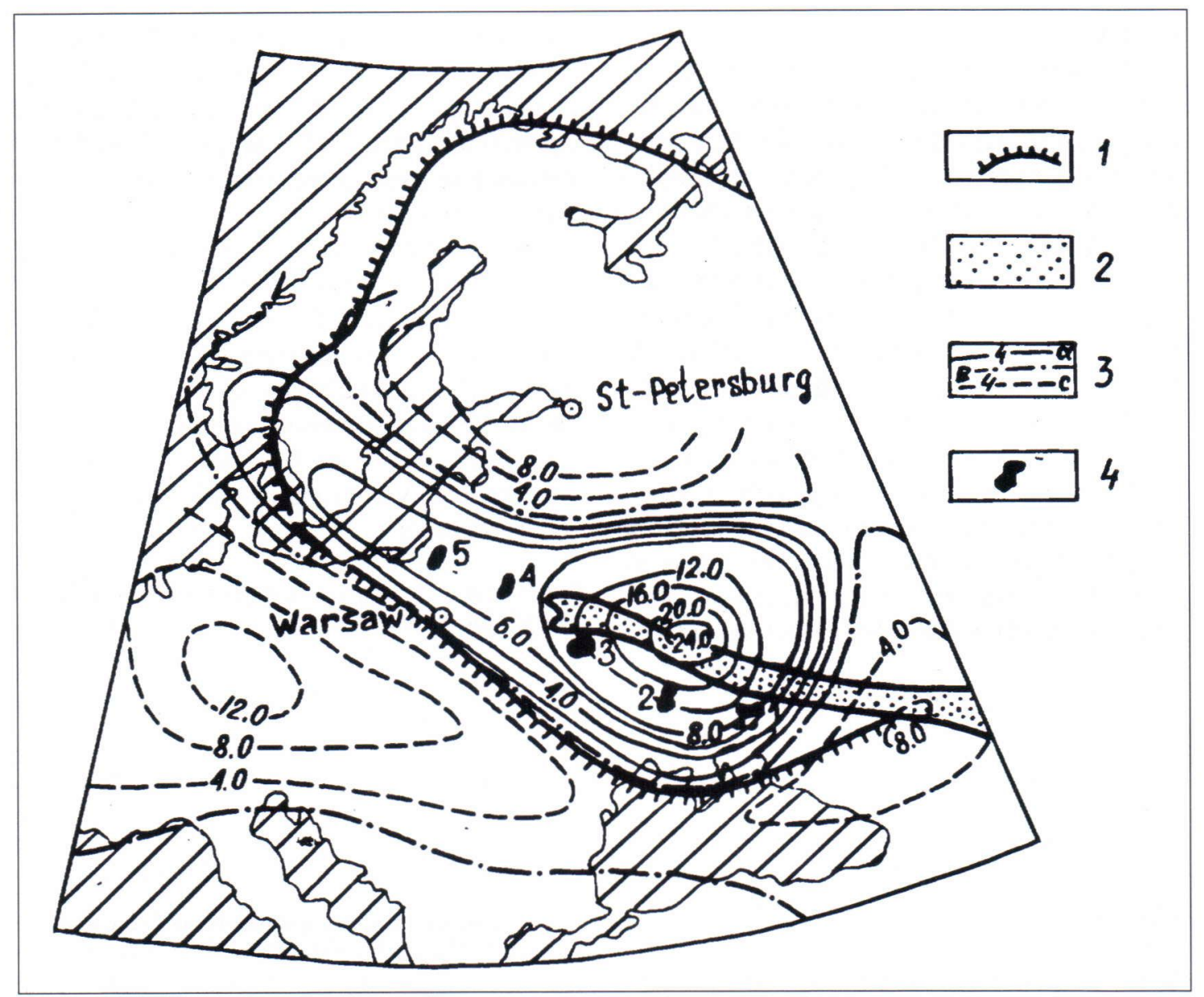

Fig. 6. Sketch map of spatial disribution of the Early Proterozoic anorogenic granitoids within a MAGSAT magnetic anomaly in the East European Platform. 1 = boundary of the East European Platform, $2=$ DnieperDonetsk Trough, $3=$ isolines of Za magnetic values $(a=$ positive, $b=z$ ero, $c=$ negative $)$. Massifs of anorogenic granitoids: 1 = East-Peri-Azov, 2 = Korsun-Novomirgorod, 3 = Korosten, $4=$ massifs of the Zhidkovichsk and Mostovsk complexes (in Belarussia), 5 = massifs of the Mazursk complex (in Poland).

(2) The evolution of the Early Precambrian granitoid magmatism of the Ukrainian shield proceeded by a successive devlopment of granitoids of the S, I and A-granite types, related to magmatic chambers becoming successively deeper. Such a development defined some specific features in evolutional trend of granitoid composition within each association. The composition of granitoids of the granitic association evolved toward increase of aluminosity; that of the diorite-granitic association toward increase of alkalinity and aluminosity, that of the anorthosite-granitic association toward increase of alkalinity (Fig.4) .
(3) As shown above (Fig. 1), spatial distributions of granitoid massif of each association are different. The granitoids of the granitic association constitute subisometric or oval-shaped areas, whereas granitoids of the diorite-granitic and anorthositegranitic associations are confined to linear structures. The areas or zones with separate granitoid massifs, or "clusters" of granitoid massifs within them are named "magmatogenic structures" (Leont'ev 1982). Within each of such areas separate massifs or groups of them are "dispersed", whereas in geophysical fields they are reflected as uniform, continuous anomalies, induced by some deep crustal 
sources.

(4) The magmatogenic structures are of at least two categories. The first one is represented by areal groups of massifs evidently originating from one or several magma chambers. They are named "chamber magmatogenic structures" (Izoch 1981). Their areal extent does not exceed several hundreds of $\mathrm{km}^{2}$ (Fig. 1). The magmatogenic structures of the second category are of transregional linear extention. The Volyno-Polessk volcano-plutonic belt and the northwestern lineament, controlling the chain-like distribution of the anorogenic granitoids, should be assigned to the second category of magmatogenic structures. It is obvious, that the plutonic bodies of the second category could not have originated from a single magma chamber. The only plausible explanation seems to be their origin from some deep horizon of the lithosphere which should have a transregional extention. The magma chambers should be located approximately at the same depth and have the same P-T environment. The spatial age shift in granitoids of each association could be interpreted in terms of an energetic wave propagated along this horizon.

(5) The rapakivi and other anorogenic granitoids are considered to belong to the final active stage of long Late Archean-Early Proterozoic evolution of magmatism, tectonism and crust forming processes which took place on a large scale over an enormous part of the East European Platform. After that the anorogenic stage in the Riphean magmatism was confined mainly to aulacogens and the crust aquired rigidity to become a platform.

IGCP Project 315 (Rapakivi Granites and Related Rocks) Publication $\mathrm{Nr} 23$.

\section{REFERENCES}

Aksamentova, N. V. and Naidenkov I. V. 1991. Geologigheskaya karta kristallicheskogo fundamenta Belorussii i prilegayushchikh territorii. Scale 1:100,000 (Geological map of crystalline basement of Belorussia and the neighbouring territories). Minsk, 1991.

Chappel, B.W. and White A. J. R. 1974. Two contrasting granite types. Pacific Geology 8, 173-174.

Chekunov, A. V. and Pashkevich I. K. 1989. Tectonic nature of the magnetic inhomogenities in the lithosphere of Ukraine. Doklady Akad. Nauka, Ukrainian SSR, Serie B, Number 5, 22-26.

Gintov, O. B. 1974. Korosten complex pluton as a giant ring tectono-magmatic structure. Geol. Zhurnal34,1218. Kiev 1974.

Esipchuk, K. E. 1988. Petrologo-geochimicheskie osnovy formatsionnogo anliza granitoidov dokembriya (Petrologo-geochemical principles of formational analysis of Precambrian granitoids). Naukova Dumka, Kiev 1988, 261 pp.

Esipchuk, K. E. 1990. Petrologiya, geochimiya i rudonosnost intruzivnych granitoidov ukraiskogo shchita (Petrology, geochemistry and ore-bearing potential of intrusive granitoids of the Ukrainian shield), Naukova Dumka, Kiev 1990. 236 pp.

Haines, G. V. 1985. MAGSAT vertical field anomalies above $40 \mathrm{~N}$ from spherical Cap. Harmonic Analysis. Journal of the Geophysical Research NB3, 25932598.

Izoch, E. P. 1981. Principles for distinguishing of granitoid formation with various metallogenic specialization for ore prognosis. Magmaticheskie formatsii, voprosy ikh proischozhdeniya i rudonosnosti, 12-20. Novosobirsk1981.

Leont'ev, A. N. 1982. Granitoidnyi magmatism i voprosy geodinamiki. (Granitoid magmatism and problems of geodynamics). Nauka, Moscow 1982. 200 pp.

Lichak, I. L. 1983. Petrologiya Korostenskogo plutona. (Petrology of the Korosten pluton). Naukova Dumka. Kiev 1983. 144 pp.

Pitcher, W. S. 1983. Granite type and tectonic environment. In: Hsu, K. (ed.); Mountain Building Processes, 19-40. Academic Press, London, 1983,

Shcherbak, N. P. (ed.) 1984. Granitoidnye formatsii ukrainskogo shchita.(Granitoid formations of the Ukrainian Shield). Naukova Dumka. Kiev 1984. 192 pp. 
Shcherbak, N.P. (ed.) 1989. Geochoronologicheskaya shkala dokembriya ukrainskogo shchita (Geochronological scale of the Precambrian of the Ukrainian shield). Naukova Dumka. Kiev 1989. 140 pp.

Sollogub V. B. 1986. Litosfera Ukrainy (Lithosphere of Ukraine). Naukova Dumka. Kiev 1986, 183 pp.

Sukhorukov, Yu. T. 1989. The rapakivi of East European Platform in the USSR. IGCP Symposium; Precambrian Granitoids. Helsinki 1989. Abstracts, p. 126.

Sukhorukov, Yu. T. and Sveshnikov K. I. 1991. Subalkaline granitoids of the central part of the Ukrainian shield; on the problem of orogenic-anorogenic characteristics of Proterozoic granitoids. IGCP project 315 Symposium. Helsinki1991. Abstracts p. 50.
Sveshnikov, K. I. 1981. On age chronology of rocks in the Korsun-Novomirgorod pluton. Geol. Zhurnal 41. Kiev 1981.

Verkhoglyad, V. M. 1988. Vozrastnye etapy formirovaniya kontinental'noi kory Volynskogo megabloka ukrainskogo shchita. (Age stages of formation of continental crust of the Volynian megablock of the Ukrainian Shield in Proterozoic). Canditate thesis. Institute of Geochemistry and Physics of Minerals, Ukrainian Acad. Sci. Kiev, 1988. 22 pp.

Windley, B. F. 1991. Early Proterozoic collision tectonics and rapakivi granites as intrusions in an extensional thrutst-thicked crust: the Ketilidian orogen, South Greenland. Tectonophysics 191, 1-10. 